University of Wollongong

Research Online

Faculty of Engineering - Papers (Archive)

Faculty of Engineering and Information

Sciences

$1-1-2011$

\title{
Highly porous metal oxide polycrystalline nanowire films with superior performance in gas sensors
}

Jun Liu

junliu@uow.edu.au

Zaiping Guo

University of Wollongong, zguo@uow.edu.au

Kaixing Zhu

Chinese Academy of Sciences, Beijing

Wenjun Wang

Institute of Physics Chinese Academy of Sciences

Chaofeng Zhang

University of Wollongong, czhang@uow.edu.au

See next page for additional authors

Follow this and additional works at: https://ro.uow.edu.au/engpapers

https://ro.uow.edu.au/engpapers/1415

\section{Recommended Citation}

Liu, Jun; Guo, Zaiping; Zhu, Kaixing; Wang, Wenjun; Zhang, Chaofeng; and Chen, Xiaolong: Highly porous metal oxide polycrystalline nanowire films with superior performance in gas sensors 2011, 11412-11417. https://ro.uow.edu.au/engpapers/1415

Research Online is the open access institutional repository for the University of Wollongong. For further information contact the UOW Library: research-pubs@uow.edu.au 


\section{Authors}

Jun Liu, Zaiping Guo, Kaixing Zhu, Wenjun Wang, Chaofeng Zhang, and Xiaolong Chen 


\title{
Journal of

\section{Highly porous metal oxide polycrystalline nanowire films with superior performance in gas sensors $\dagger$}

\author{
Jun Liu, ${ }^{a}$ Zaiping Guo, ${ }^{* a}$ Kaixing Zhu, ${ }^{b}$ Wenjun Wang, ${ }^{b}$ Chaofeng Zhang ${ }^{a}$ and Xiaolong Chen ${ }^{* b}$ \\ Received 4th February 2011, Accepted 19th May 2011 \\ DOI: 10.1039/c1jm10537j
}

\begin{abstract}
In this work, we report for the first time a simple two-step route to fabricate a novel porous metal oxide film composed of polycrystalline nanowires with ultra-small nanoparticles, good interconnectivity between nanoparticles, and a high density of ultra-fine nanopores. The as-prepared metal oxide films combine the advantages of small crystal size, high surface-to-volume ratio, and one-dimensionalnanowire-induced unique charge transport paths (with correspondingly high interconnectivity). Taking $\mathrm{In}_{2} \mathrm{O}_{3}$ as an example, porous $\operatorname{In}_{2} \mathrm{O}_{3}$ films, composed of polycrystalline $\operatorname{In}_{2} \mathrm{O}_{3}$ nanowires with ultra-small nanocrystals (less than $10 \mathrm{~nm}$ ) and a high density of ultra-fine nanopores $(1.6-3.1 \mathrm{~nm})$, have shown very high sensitivity and good reproducibility towards ethanol gas, which are 10-20 times higher than for $\mathrm{In}_{2} \mathrm{O}_{3}$ octahedra and commercial $\mathrm{SnO}_{2}$ thick films. The response/recovery speeds of the as-prepared porous $\mathrm{In}_{2} \mathrm{O}_{3}$ films are also 5-6 times higher than for $\mathrm{In}_{2} \mathrm{O}_{3}$ octahedra, $\mathrm{SnO}_{2}$ nanobelts, and commercial $\mathrm{SnO}_{2}$ thick films. We believe that such metal oxide flexible films made from highly porous nanowires will replace their traditional thick film counterparts, not only in gas sensors but also in other functional devices, such as batteries, supercapacitors, solar cells, etc.
\end{abstract}

\section{Introduction}

Almost half a century ago, it was realized that semiconducting metal oxides had great potential as gas-sensing materials, ${ }^{1}$ owing to the fact that the chemical interaction of gas molecules with the semiconductor surface leads to changes in the electrical conductivity. Such "chemiresistors" can be manufactured as portable devices that can be operated at elevated temperature by battery power and used in a large variety of applications, such as fire detectors, leakage detectors, controllers of ventilation in cars and airplanes, and alarm devices warning that concentrations of hazardous gases have exceeded preset thresholds in workplaces. They can even be used for the detection of smells generated from food or household products and for analysis of complex environmental mixtures. ${ }^{2-5}$ The sensing material is usually deposited as a thick solid film or layer on a substrate with electrodes, as shown in Scheme 1(a). Such ethanol sensors based on $\mathrm{SnO}_{2}$ thick films have been commercialized for years. However, the gas

${ }^{a}$ Institute for Superconducting and Electronic Materials, University of Wollongong, NSW, 2522, Australia. E-mail: zguo@uow.edu.au; Fax: +612 4221 5731; Tel: +61242215225

${ }^{b}$ Beijing National Laboratory for Condensed Matter Physics, Institute of Physics, Chinese Academy of Sciences, Beijing, 100190, China. E-mail: chenx29@aphy.iphy.ac.cn; Fax: +86-010-82649646; Tel: +86-01082649036

$\uparrow$ Electronic supplementary information (ESI) available: Photograph of synthesized gram-scale InN nanowires, SEM images of InN nanowires, experimental details for synthesis of $\mathrm{In}_{2} \mathrm{O}_{3}$ octahedra and $\mathrm{SnO}_{2}$ nanobelts, together with XRD patterns and SEM images. See DOI: 10.1039/c1jm10537j a) commercial dense film

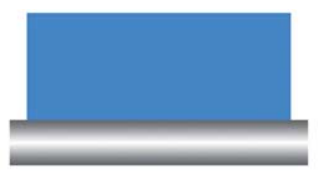

(side view)

b) nanoparticulate film

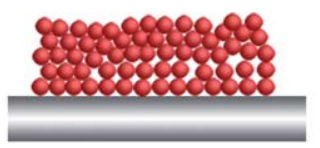

(side view)

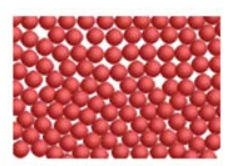

(top view) c) novel porous polycrystalline nanowire film

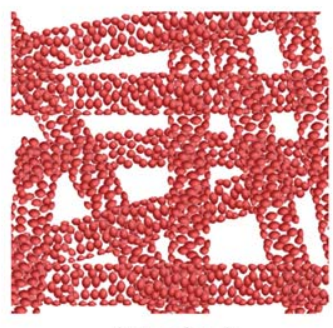

(top view)

Scheme 1 Schematic diagrams of gas sensor films: (a) commercial dense film, which suffers from large crystal sizes and low surface area; (b) nanoparticulate film, in which it is difficult to achieve both large surface area (realized by low grain interconnectivity) and high stability/electronic conductance (resulting from high grain interconnectivity); (c) novel porous polycrystalline nanowire film with small nanocrystal sizes, ultrahigh surface area, and one-dimensional (1D)-nanowire-induced unique charge transport paths (with correspondingly high interconnectivity). 
sensitivities of these traditional thick, dense films have been intrinsically restricted by their large crystal sizes and low surface areas, and applications of these traditional thick films are also limited by their lack of flexibility. Although atomic layer deposition (ALD) $)^{5,6}$ and molecular beam epitaxy $(\mathrm{MBE})^{7}$ have been recently used to produce dense films with thicknesses within the Debye length, $\delta$ (such as $\delta \approx 3 \mathrm{~nm}$ for $\mathrm{SnO}_{2}$ at $250{ }^{\circ} \mathrm{C}$ ), ${ }^{8}$ from the viewpoint of high gas sensitivity, these dense films still suffer from high sensor resistance and poor mechanical stability.

In 1991, Yamazoe demonstrated that reduction in the crystal size of metal oxides would significantly increase their sensor performance. ${ }^{9}$ This is because the grains of nanomaterials are almost depleted of carriers, and changes in the surface oxygen concentration significantly affect the whole semiconductor, resulting in high sensitivity. ${ }^{10}$ Therefore, in the past two decades, many wet and dry methods, such as sol-gel synthesis, ${ }^{\mathbf{1 1}, 12}$ chemical or physical vapor deposition, ${ }^{13,14}$ spray pyrolysis, ${ }^{15}$ pulsed laser deposition, ${ }^{16}$ and sputtering, ${ }^{17}$ have been developed to synthesize metal oxide nanoparticles and assemble them into nanoparticulate films, as shown in Scheme 1(b). The main advantage of nanoparticulate films in comparison to dense films is that it is not necessary to decrease the film thickness down to the Debye length of the oxide to reach high sensitivity. However, to date, it is still difficult to achieve controlled production of nanoparticulate films with both large surface areas (realized by low grain agglomeration) and high stability/electronic conductance (resulting from high grain interconnectivity). Therefore, new methods and technologies for fabrication of small nanocrystals with both high grain interconnectivity and large surface areas must be developed.

Synthesis of porous metal oxide films is also a good method to enhance gas sensitivity due to their high surface areas. Most syntheses of porous metal oxide films reported so far have focused on template-assisted methods. ${ }^{18,19}$ Recently, there have been a few reports on the preparation of porous metal oxide powders by chemical conversion methods, such as chemical conversion from $\mathrm{CdCO}_{3}$ to $\mathrm{CdO},{ }^{20}$ from $\mathrm{CuS}$ to $\mathrm{CuO},{ }^{21}$ and from cobalt hydroxide to $\mathrm{Co}_{3} \mathrm{O}_{4} \cdot{ }^{22 a}$ Although these methods can produce porous metal oxide films or powders, it is still hard to separately control the film thickness, and the grain and crystal sizes. These strategies also often produce porous materials with pore sizes in the range of several tens of nanometres or up to hundreds of nanometres, due to the limitations of template sizes or large volume loss in the chemical conversion.

In this paper, we report a chemical conversion strategy to synthesize and self-assemble ultra-small metal oxide nanocrystals into polycrystalline nanowires with a high density of ultra-fine nanopores. The porous polycrystalline nanowires are then matted into a porous nanowire film (as shown in Scheme 1(c)) by a simple filtration method. Such a two-step route presents a feasible way to separately control the thickness of the porous film and the crystal size. The first step is based on a chemical conversion from metal nitride nanowires to porous metal oxide polycrystalline nanowires. Compared to previous work, ${ }^{20-22 a}$ our porous metal oxides produced by a chemical conversion from metal nitrides feature ultra-fine nanopores. Herein, taking $\mathrm{In}_{2} \mathrm{O}_{3}{ }^{22 b-d}$ as an example, porous $\mathrm{In}_{2} \mathrm{O}_{3}$ films, composed of polycrystalline $\mathrm{In}_{2} \mathrm{O}_{3}$ nanowires with ultra-small nanocrystals (less than $10 \mathrm{~nm}$ ) and a high density of ultra-fine nanopores (1.6-
$3.1 \mathrm{~nm}$ ), have been successfully synthesized and show very high sensitivity towards ethanol gas, 10-20 times higher than for commercial $\mathrm{SnO}_{2}$ thick films. The response/recovery speeds of the as-prepared porous $\mathrm{In}_{2} \mathrm{O}_{3}$ films are also 5-6 times higher than for $\mathrm{SnO}_{2}$ nanobelts and commercial $\mathrm{SnO}_{2}$ thick films. At the same time, these tunable, scalable, and reproducible porous metal oxide films can also be readily integrated into flexible gas sensor devices. We believe that such deliberately designed thin, flexible metal oxide films made from highly porous nanowires will replace their traditional thick film counterparts, not only in gas sensors but also in other applications, such as catalysts, batteries, supercapacitors, solar cells, etc., due to their much smaller crystal size, higher surface-to-volume ratio, and unique charge transport paths.

\section{Experimental}

The synthesis of the novel $\mathrm{In}_{2} \mathrm{O}_{3}$ films made from porous $\mathrm{In}_{2} \mathrm{O}_{3}$ nanowires consists of a two-step route. Synthesis of porous $\mathrm{In}_{2} \mathrm{O}_{3}$ nanowires is based on a chemical conversion: $\operatorname{In}_{2} \mathrm{O}_{3}$ powder $(3 \mathrm{~g}$, $99.99 \%$ ) is put into an ethanol solution for ultrasonic treatment, and then, this solution containing $\operatorname{In}_{2} \mathrm{O}_{3}$ powder is evenly coated on the walls of a quartz boat $(23 \mathrm{~cm} \times 3 \mathrm{~cm} \times 1.5 \mathrm{~cm})$ by slowly drying it. The quartz boat is placed in the central heating zone of the quartz tube in a tube furnace. The quartz tube is pumped and then filled with pure ammonia $\left(\mathrm{NH}_{3}\right)$. After repeating the operation three times, the quartz tube is heated to $660{ }^{\circ} \mathrm{C}$ in half an hour under a pure ammonia flow of 400 standard cubic centimetres per minute $(\mathrm{sccm})$ and normal pressure. After the quartz tube has been kept at this temperature for 24 hours, it is naturally cooled. Then, the large amount of wool-like product ( $\mathrm{InN}$ nanowires) in the quartz boat is heated to $600{ }^{\circ} \mathrm{C}$ in 180 minutes under air atmosphere. After it is annealed for 2 hours at this temperature, it is naturally cooled. The synthesis of porous $\operatorname{In}_{2} \mathrm{O}_{3}$ nanowire film is based on a simple filtration method: the annealed products (porous $\operatorname{In}_{2} \mathrm{O}_{3}$ nanowires) are collected and put into $50 \mathrm{ml}$ of Milli-Q water, followed by stirring for several minutes. A porous anodic aluminium oxide (AAO) membrane with a pore size of $220 \mathrm{~nm}$ acts as a filter paper. Passing the prepared $\mathrm{In}_{2} \mathrm{O}_{3}$ suspension through the AAO filter in a filtration cell under a positive nitrogen gas pressure of $400 \mathrm{kPa}$ produces a flexible mat of entangled porous $\mathrm{In}_{2} \mathrm{O}_{3}$ nanowires, known as a "bucky paper" from its carbon nanowire equivalent. The $\operatorname{In}_{2} \mathrm{O}_{3}$ nanowire mat is peeled off the AAO filter after letting it dry overnight in a vacuum oven. The thickness of the $\operatorname{In}_{2} \mathrm{O}_{3}$ nanowire paper can be easily tuned by changing the amount of porous $\mathrm{In}_{2} \mathrm{O}_{3}$ nanowires.

Phase identifications were performed on an X-ray diffractometer (Philips X'PERT MPD) with $\mathrm{Cu} \mathrm{K} \alpha$ radiation $(\lambda=$ $1.5406 \AA$ A), operated at $40 \mathrm{kV}$ and $40 \mathrm{~mA}$. The morphologies and microstructures of the product were characterized using scanning electron microscopy (Hitachi, S-4200) and transmission electron microscopy (Philip, CM-2000FEG). The Brunauer-EmmettTeller (BET) surface area measurement and pore analysis were carried out by nitrogen adsorption with the use of a Micromeritics ASAP $2020 \mathrm{~V} 3.00 \mathrm{H}$ surface area analyser. The measurement was carried out at liquid nitrogen temperature after degassing the powder sample at $250^{\circ} \mathrm{C}$. The thermogravimetric/ differential thermal analysis (TGA-DTA) experiment was 
performed on an SDT Q600 (V20.9 Build 20) instrument. InN nanowires were put into an alumina crucible and heated in air at $10{ }^{\circ} \mathrm{C} \mathrm{min}^{-1}$ from room temperature to a final temperature of $800^{\circ} \mathrm{C}$.

The gas-sensing tests were performed in a WS-60A measurement system (Zhengzhou Winsen Electronics Technology, China). In a typical test, a gas sensor was fabricated by attaching a porous $\operatorname{In}_{2} \mathrm{O}_{3}$ nanowire film onto a ceramic disk that had been previously mounted with gold electrodes and platinum conducting wires (ESI $\dagger$, Fig. S1). A resistor wire was inserted under the disk as a heater to provide working temperatures from 200 to $500{ }^{\circ} \mathrm{C}$ by varying the heating current. The ethanol was injected onto a metal-plate heater in the test chamber and evaporated completely by heating. The gas-sensing capability of the sensor was defined as the ratio $R_{\text {gas }} / R_{\text {air }}$, where $R_{\text {gas }}$ and $R_{\text {air }}$ are the electrical resistance of the sensor in test gas and in air at the working temperature of about $260{ }^{\circ} \mathrm{C}$, respectively.

\section{Results and discussion}

Fig. 1 shows X-ray diffraction (XRD) patterns of the products, as-obtained by nitriding $\operatorname{In}_{2} \mathrm{O}_{3}$ powders (a) and after further annealing for 2 hours in air (b). The XRD pattern of the products in the first step can be well indexed to a hexagonal cell with $a=$ $b=3.538 \AA$ and $c=5.703 \AA$, in good agreement with the standard data (ICDD-PDF 50-1239), confirming that the product obtained by nitriding $\operatorname{In}_{2} \mathrm{O}_{3}$ is $\mathrm{InN}$ with a hexagonal structure. The XRD pattern of the product annealed for 2 hours in air can be well indexed to a cubic cell with $a=b=c=10.140 \AA$, in good agreement with the standard data (ICDD-PDF 65-3170), confirming that this product is pure $\mathrm{In}_{2} \mathrm{O}_{3}$ with a cubic structure. According to the full width at half maximum (FWHM) of each peak in the XRD patterns, it can be deduced from the Scherrer formula that the crystal sizes of $\operatorname{In}_{2} \mathrm{O}_{3}(5-10 \mathrm{~nm})$ are much smaller than those of InN (about $40 \mathrm{~nm}$ ).

The photograph in Fig. S2(a)† shows the gram-scale synthesis of rufous wool-like $\mathrm{InN}$ obtained in the first step, which is sufficient to fill up a quartz boat $(23 \mathrm{~cm} \times 3 \mathrm{~cm} \times 1.5 \mathrm{~cm})$. The scanning electron microscope (SEM) images in Fig. S2(b) and (c) $\dagger$ show that the synthesized wool-like InN consists of a large amount of nanowires with a uniform diameter of around $40 \mathrm{~nm}$. The transmission electron microscope (TEM) image in Fig. S2

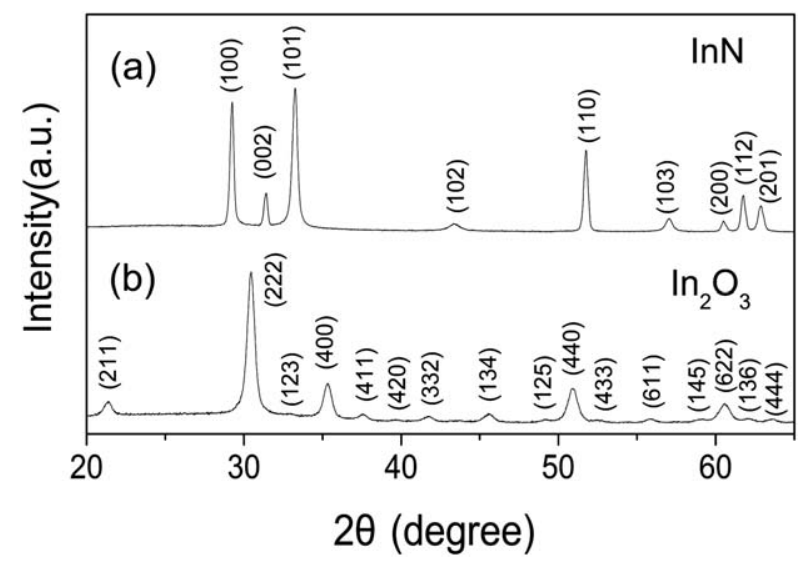

Fig. 1 XRD patterns of the product in the first step (a) and the product after annealing for 2 hours at $600{ }^{\circ} \mathrm{C}$ in air (b). (d) $\dagger$ and the corresponding high resolution TEM (HRTEM) image in Fig. S2(e) $\dagger$ indicate that these InN nanowires are single crystals with excellent crystallinity and grow along the [001] direction. The photograph in Fig. 2(a) shows the gram-scale synthesis of a yellowish wool-like product in the second step, also sufficient to fill up a quartz boat $(23 \mathrm{~cm} \times 3 \mathrm{~cm} \times 1.5 \mathrm{~cm})$. The SEM image in Fig. 2(b) shows that the synthesized wool-like product consists of a large amount of $\mathrm{In}_{2} \mathrm{O}_{3}$ nanowires with a uniform diameter of about $40 \mathrm{~nm}$. The TEM images in Fig. 2(c) and $\mathrm{S} 3(\mathrm{a}) \dagger$ indicate that the as-synthesized $\operatorname{In}_{2} \mathrm{O}_{3}$ nanowire is polycrystalline and has a preferred orientation along the [222] direction, which is demonstrated in the corresponding selected area electron diffraction (SAED) pattern (inset in Fig. S3(a) $\dagger$ ). Moreover, it is interesting to note that these $\operatorname{In}_{2} \mathrm{O}_{3}$ nanowires all have a high density of nanopores, as shown in Fig. S3(b) and (c) $\dagger$.

Nitriding $\mathrm{In}_{2} \mathrm{O}_{3}$ in an $\mathrm{NH}_{3}$ flux to synthesize $\mathrm{InN}$ micro- and nanostructures has been reported by some groups. ${ }^{23-25}$ Compared to these previous works, we have scaled up the reaction to demonstrate its potential for gram-scale synthesis of long InN nanowires with a uniform diameter of about $40 \mathrm{~nm}$ by in situ nitriding of $\operatorname{In}_{2} \mathrm{O}_{3}$ commercial micropowders. Because no catalyst is involved, the vapor-solid (VS) mechanism should account for the formation of the InN nanowires. The formation of porous $\mathrm{In}_{2} \mathrm{O}_{3}$ nanowires with a high density of ultra-fine nanopores is illustrated in Scheme 2. Thermodynamically, the oxidation reaction $\left(2 \mathrm{InN}+(3 / 2) \mathrm{O}_{2} \rightarrow \mathrm{In}_{2} \mathrm{O}_{3}+\mathrm{N}_{2}\right)$ is expected to occur readily when $\mathrm{InN}$ is exposed to an oxygen-containing atmosphere, due to the large difference in the heat of formation at room temperature between $\mathrm{InN}\left(-4.2 \mathrm{kcal} \mathrm{mol}^{-1}\right)$ and $\mathrm{In}_{2} \mathrm{O}_{3}$ $\left(-221.27 \mathrm{kcal} \mathrm{mol}^{-1}\right),{ }^{26}$ as shown in Scheme 2(A). The DTATGA curves obtained for the InN precursor under air atmosphere are shown in Fig. S4 $\uparrow$. At the beginning of the thermal oxidation of $\mathrm{InN}$, a thin $\operatorname{In}_{2} \mathrm{O}_{3}$ shell is formed on the surface of these nanowires. This thin layer acts as an interface and prevents the inner InN from coming into direct contact with the outer atmospheric oxygen. However, the interface consists of an intermediate shell with many vacancies. This kind of shell

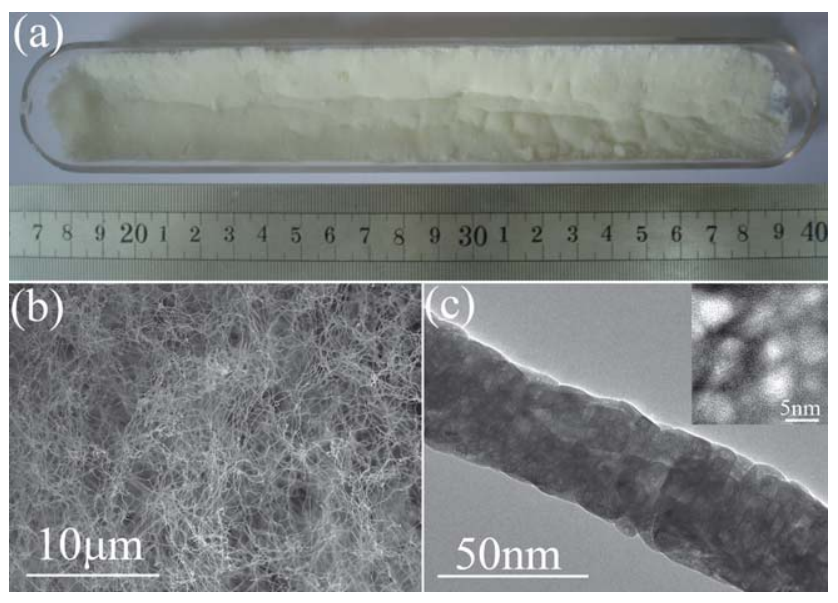

Fig. 2 (a) Photograph of gram-scale synthesized porous $\operatorname{In}_{2} \mathrm{O}_{3}$ nanowires; (b) SEM image of the as-synthesized porous $\operatorname{In}_{2} \mathrm{O}_{3}$ nanowires created by a chemical conversion from InN nanowires; (c) TEM image and HRTEM image (inset) of an as-synthesized porous $\operatorname{In}_{2} \mathrm{O}_{3}$ nanowire, showing its high density of ultra-fine nanopores. 
Reaction at precursor surfaces
(A)

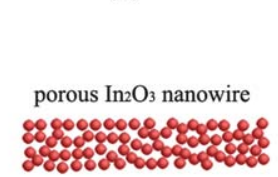

(D)

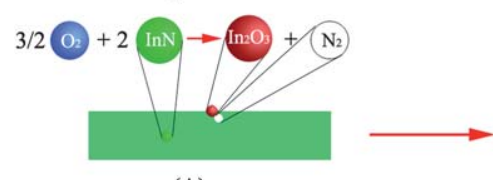

Non-equilibrium interdiffusion induced Kirkendall voids

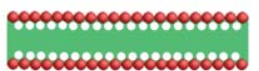

(B)

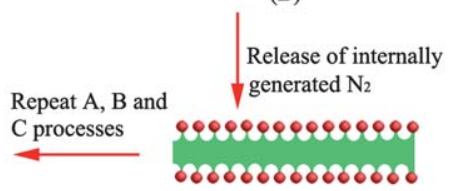

(C)

Scheme 2 Schematic diagram of the procedure used to fabricate porous $\mathrm{In}_{2} \mathrm{O}_{3}$ hollow architectures: (A) uniform $\mathrm{InN}$ is used as the starting precursor; (B) formation of $\operatorname{In}_{2} \mathrm{O}_{3}$ shell on the surface of $\mathrm{InN}$ in the thermal oxidation process, with Kirkendall voids formed at the interface which results from the non-equilibrium interdiffusion; (C) formation of porous $\operatorname{In}_{2} \mathrm{O}_{3}$ shell on the surface of InN, which results from volume loss and release of internally generated $\mathrm{N}_{2}$; (D) A, B, and C processes are repeated to chemically convert $\mathrm{InN}$ nanowires into highly porous $\mathrm{In}_{2} \mathrm{O}_{3}$ nanowires.

structure allows the outward diffusion of the inner nitrogen atoms and vacancies, and the inward diffusion of oxygen. Since the outward diffusion rate of the inner nitrogen is larger than the inward diffusion rate of atmospheric oxygen during the oxidation reactions, small voids are thus generated in the interface of InN/ $\mathrm{In}_{2} \mathrm{O}_{3}$ (as shown in Scheme 2(B)). Such non-equilibrium interdiffusion is known as the "Kirkendall Effect", which has been introduced into nanomaterial synthesis (such as in the synthesis of nanocrystals, ${ }^{27}$ peashell-like nanostructures, ${ }^{28}$ and nanotubes ${ }^{29}$ ) and has been well explained by Fan et al. ${ }^{30}$ The newly formed $\mathrm{In}_{2} \mathrm{O}_{3}$ shell forms a coating on the $\mathrm{InN}$ nanowires, which can effectively block the release of internally generated gas. More gas accumulates gradually in the interior of the structure until the pressure is increased to the point where the structure is broken to form a small pore, and finally, a porous shell is formed, as shown in Scheme 2(C). Once the porous shell is formed, the atmospheric oxygen can directly react with the inner InN, by a process which is similar to the thermal oxidation of InN nanowires in the very beginning. Then, the $\operatorname{In}_{2} \mathrm{O}_{3}$ shell can be formed again, and small voids will be generated in the interface. Such a process will be repeated until the whole InN nanowire has been transformed into a porous $\mathrm{In}_{2} \mathrm{O}_{3}$ polycrystalline nanowire, as shown in Scheme 2(D). Therefore, the formation of porous $\mathrm{In}_{2} \mathrm{O}_{3}$ nanowires is based on non-equilibrium interdiffusion (the Kirkendall effect), volume loss, and gas release. Moreover, it is interesting that the as-synthesized porous $\operatorname{In}_{2} \mathrm{O}_{3}$ nanowires produced by chemical conversion from $\mathrm{InN}$ have ultra-fine nanopores $(1.6-3.1 \mathrm{~nm})$ compared to those previously reported. For example, in reducing $\mathrm{Mn}_{3} \mathrm{O}_{4}$ to $\mathrm{MnO}$, the pore sizes are about $50 \mathrm{~nm} ;{ }^{31}$ in oxidising $\mathrm{CuS}$ to synthesize $\mathrm{CuO}$, the pore sizes are about $100 \mathrm{~nm} ;{ }^{21}$ in annealing $\mathrm{Co}(\mathrm{OH})_{2}$ to synthesize $\mathrm{Co}_{3} \mathrm{O}_{4}$, the pore sizes are about $50 \mathrm{~nm} ;{ }^{22 a}$ and in annealing $\mathrm{CdCO}_{3}$ to synthesize $\mathrm{CdO}$, the pore sizes are about $50 \mathrm{~nm}{ }^{20}$ This is possibly because the diameter of the as-synthesized $\operatorname{InN}$ nanowires is less than $50 \mathrm{~nm}$, and such small $\mathrm{InN}$ nanowires as starting reactants will enhance $\mathrm{N}_{2}$ gas release, so as to avoid large pore formation. However, in those microscale materials

previously reported as starting reactants, gas diffusion over long distances is required.

In order to fabricate a sensor film with small crystal size, high surface area, and high grain interconnectivity, these porous and polycrystalline $\mathrm{In}_{2} \mathrm{O}_{3}$ nanowires are filtered in a filtration cell under a positive nitrogen gas pressure of $400 \mathrm{kPa}$ to produce a tight and flexible mat of entangled porous $\operatorname{In}_{2} \mathrm{O}_{3}$ nanowires, known as a "bucky paper". Fig. 3(a) presents a photograph of the flexible film. The flexible film with entangled porous $\operatorname{In}_{2} \mathrm{O}_{3}$ nanowires is also shown in an enlarged SEM image (Fig. 3(b)). The specific surface area and pore size distribution of the porous $\mathrm{In}_{2} \mathrm{O}_{3}$ nanowire film were measured by BET $\mathrm{N}_{2}$ adsorption after degassing at $250{ }^{\circ} \mathrm{C}$ for $12 \mathrm{~h}$, as shown in Fig. 4. It can be seen that the specific surface area is as high as $185.38 \mathrm{~m}^{2} \mathrm{~g}^{-1}$. The pore size distribution in the film ranged from $1.6 \mathrm{~nm}$ to $3.1 \mathrm{~nm}$, and from $10 \mathrm{~nm}$ to $250 \mathrm{~nm}$, with a maximum at $2.2 \mathrm{~nm}$. The pores ranging from $1.6 \mathrm{~nm}$ to $3.1 \mathrm{~nm}$ correspond to the small pores formed in $\mathrm{In}_{2} \mathrm{O}_{3}$ nanowires, but the pores ranging from $10 \mathrm{~nm}$ to $250 \mathrm{~nm}$ correspond to the holes between the different $\mathrm{In}_{2} \mathrm{O}_{3}$ nanowires.

Such a novel flexible film can be readily cut into a small sheet and simply attached onto an $\mathrm{Al}_{2} \mathrm{O}_{3}$ substrate with electrodes to make a sensor device (Fig. S1 $\dagger$ ). Fig. 5 shows the gas sensitivity and response/recovery speeds of the as-prepared porous $\mathrm{In}_{2} \mathrm{O}_{3}$ nanowire films compared to $\mathrm{In}_{2} \mathrm{O}_{3}$ octahedra, commercial $\mathrm{SnO}_{2}$ thick, dense films, and $\mathrm{SnO}_{2}$ nanobelts towards different concentrations of ethanol gas at $260{ }^{\circ} \mathrm{C}$. $\left(\mathrm{SnO}_{2}\right.$ is the most widely used gas sensing material.) The experimental details for largescale synthesis of $\mathrm{In}_{2} \mathrm{O}_{3}$ octahedra and $\mathrm{SnO}_{2}$ nanobelts, along with the XRD patterns and SEM images of these $\operatorname{In}_{2} \mathrm{O}_{3}$ octahedra and as-synthesized $\mathrm{SnO}_{2}$ nanobelts, are shown in the ESI $\dagger$. It can be seen that the sensors using porous $\mathrm{In}_{2} \mathrm{O}_{3}$ nanowire films show stable response and recovery behavior. The gas responses of porous $\mathrm{In}_{2} \mathrm{O}_{3}$ nanowire films $\left(R_{\text {air }} / R_{\text {gas }}, R_{\text {air }}\right.$ : resistance in air, $R_{\text {gas }}$ : resistance in gas) to $2,20,50$, and $100 \mathrm{ppm} \mathrm{C}_{2} \mathrm{H}_{5} \mathrm{OH}$ are up to $2.06,14.88,38.6$, and 62.6 , respectively, which are 10-20 times higher than for $\mathrm{In}_{2} \mathrm{O}_{3}$ octahedra and commercial $\mathrm{SnO}_{2}$ thick films. The times to reach $90 \%$ variation in resistance upon exposure to $\mathrm{C}_{2} \mathrm{H}_{5} \mathrm{OH}$ and air are defined as the $90 \%$ response time $\left(\tau_{\text {res }}\right)$ and the $90 \%$ recovery time $\left(\tau_{\text {recov }}\right)$, respectively. The $\tau_{\text {res }}$ values of the porous $\operatorname{In}_{2} \mathrm{O}_{3}$ nanowire films upon exposure to 2, 20, 50, and $100 \mathrm{ppm}_{2} \mathrm{H}_{5} \mathrm{OH}$ are 6, 4, 3, and $5 \mathrm{~s}$, respectively, whereas the $\tau_{\text {res }}$ values of $\mathrm{In}_{2} \mathrm{O}_{3}$ octahedra on average are $30 \mathrm{~s}$, the $\tau_{\text {res }}$ values of $\mathrm{SnO}_{2}$ nanobelts on average are $23 \mathrm{~s}$, and the $\tau_{\text {res }}$ values of the commercial $\mathrm{SnO}_{2}$ thick films are $20 \mathrm{~s}$. The $\tau_{\text {recov }}$
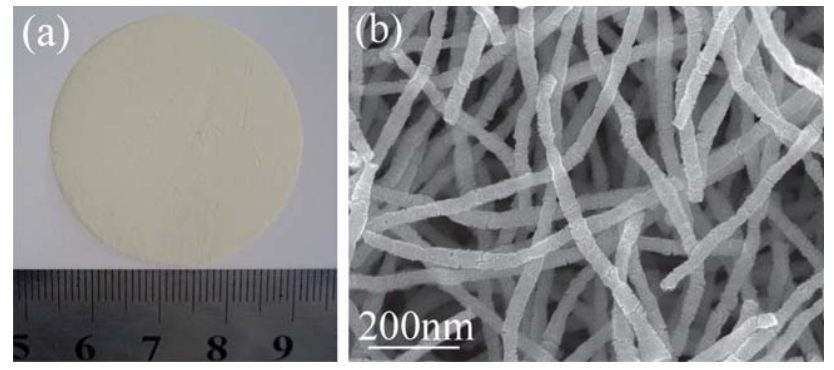

Fig. 3 Photograph (a) and enlarged SEM image (b) of a porous $\mathrm{In}_{2} \mathrm{O}_{3}$ nanowire film. 


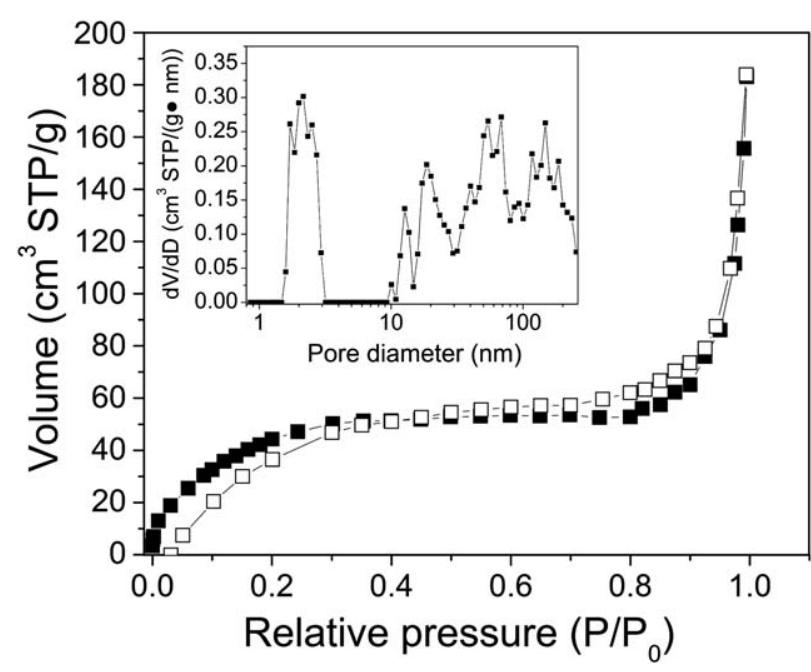

Fig. $4 \mathrm{~N}_{2}$ adsorption-desorption isotherms and pore size distribution (inset) of the porous $\mathrm{In}_{2} \mathrm{O}_{3}$ nanowire film.

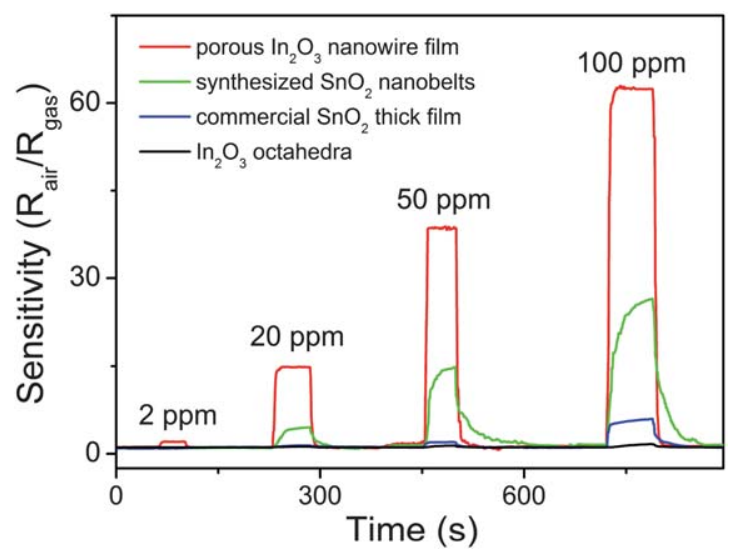

Fig. 5 The gas sensitivities and response times of porous $\operatorname{In}_{2} \mathrm{O}_{3}$ nanowire films, $\mathrm{In}_{2} \mathrm{O}_{3}$ octahedra, $\mathrm{SnO}_{2}$ nanobelts, and commercial $\mathrm{SnO}_{2}$ thick, dense films towards different concentrations of ethanol gas at $260{ }^{\circ} \mathrm{C}$.

values of the porous $\mathrm{In}_{2} \mathrm{O}_{3}$ nanowire films during recovery after exposure to 2, 20, 50, and $100 \mathrm{ppm}_{2} \mathrm{H}_{5} \mathrm{OH}$ are 7, 5, 4, and $7 \mathrm{~s}$, respectively (as is shown in Table $\mathrm{S} 1 \dagger$ ), whereas the $\tau_{\text {recov }}$ values of $\mathrm{SnO}_{2}$ nanobelts on average are $41 \mathrm{~s}$, the $\tau_{\text {recov }}$ values of $\mathrm{SnO}_{2}$ nanobelts on average are $37 \mathrm{~s}$, and the $\tau_{\text {recov }}$ values of the commercial $\mathrm{SnO}_{2}$ thick films are $30 \mathrm{~s}$. Therefore, the response/ recovery speeds of porous $\mathrm{In}_{2} \mathrm{O}_{3}$ nanowire films are 5-6 times higher than for $\mathrm{In}_{2} \mathrm{O}_{3}$ octahedra, the $\mathrm{SnO}_{2}$ nanobelts, or the commercial $\mathrm{SnO}_{2}$ thick films. The long-term stability test results on porous $\mathrm{In}_{2} \mathrm{O}_{3}$ nanowire film sensors exposed to $50 \mathrm{ppm}$ ethanol gas at $260^{\circ} \mathrm{C}$ are shown in Fig. S10†, and it can be seen that the gas sensitivity of the porous $\operatorname{In}_{2} \mathrm{O}_{3}$ nanowire film sensors can be maintained for at least 120 days. Fig. S11† shows the variation of sensitivity of porous $\operatorname{In}_{2} \mathrm{O}_{3}$ nanowire film sensors with the thickness for four values of concentrations of ethanol vapor. As is evident from the figure, the sensitivity of the sensors increases with increasing vapor concentration and decreasing thickness of the gas sensor film. Fig. S12† shows the stability of the response of porous $\mathrm{In}_{2} \mathrm{O}_{3}$ nanowire film sensors with different thicknesses to $50 \mathrm{ppm}$ ethanol gas at $260{ }^{\circ} \mathrm{C}$.
As is well known, when a metal oxide gas sensor is exposed to air, oxygen species can be adsorbed on the surface of the sensor, and then are ionized into $\mathrm{O}^{-}$or $\mathrm{O}^{2-}$ by capturing free electrons from the conductance band of the metal oxide. Therefore, as a pronounced n-type semiconductor, $\operatorname{In}_{2} \mathrm{O}_{3}$ will show a decrease in conductivity in air due to the decreased concentration of free electrons. This process can be depicted as follows: ${ }^{32}$

$$
\begin{gathered}
\mathrm{O}_{2} \text { (gas) } \leftrightarrow \mathrm{O}_{2} \text { (adsorption) } \\
\mathrm{O}_{2} \text { (gas) }+\mathrm{e} \leftrightarrow \mathrm{O}_{2}^{-} \text {(adsorption) } \\
\mathrm{O}_{2}^{-} \text {(adsorption) }+\mathrm{e} \leftrightarrow 2 \mathrm{O}^{-} \text {(adsorption) } \\
\mathrm{O}_{2}^{-} \text {(adsorption) }+\mathrm{e} \leftrightarrow \mathrm{O}^{2-} \text { (adsorption) }
\end{gathered}
$$

When the sensor is exposed to a reducing gas such as ethanol gas, the reducing gas may react with the adsorbed and ionized oxygen molecules and release the trapped electrons back into the $\mathrm{In}_{2} \mathrm{O}_{3}$ semiconductor, thereby increasing the conductivity of $\mathrm{In}_{2} \mathrm{O}_{3}$. This can simply be described as follows: ${ }^{32,33}$

$$
\begin{gathered}
\mathrm{C}_{2} \mathrm{H}_{5} \mathrm{OH}+6 \mathrm{O}^{-} \text {(adsorption) } \rightarrow 2 \mathrm{CO}_{2}+3 \mathrm{H}_{2} \mathrm{O}+6 \mathrm{e}^{-} \\
\mathrm{C}_{2} \mathrm{H}_{5} \mathrm{OH}+6 \mathrm{O}^{2-} \text { (adsorption) } \rightarrow 2 \mathrm{CO}_{2}+3 \mathrm{H}_{2} \mathrm{O}+12 \mathrm{e}^{-}
\end{gathered}
$$

Therefore, the oxygen adsorption in the first step is very important for the performance of the sensor. The excellent gas sensor properties of the as-prepared $\mathrm{In}_{2} \mathrm{O}_{3}$ flexible films may be related to the following factors: (1) crystal sizes are very small, which induces high chemical reactivity and favors the adsorption and ionization of oxygen molecules on their surfaces. In addition, such small nanosized grains of $\operatorname{~}_{2} \mathrm{O}_{3}$ (with a size approximately twice the Debye length) cause whole grains to be depleted of carriers and exhibit much poorer conductivity than $\mathrm{SnO}_{2}$ nanobelts and commercial $\mathrm{SnO}_{2}$ thick films in ambient air. (2) Surface-to-volume ratios are ultra-high, so that gas sensors containing such films can adsorb a much greater amount of oxygen molecules than the gas sensors based on $\mathrm{SnO}_{2}$ nanobelts and commercial $\mathrm{SnO}_{2}$ thick films. These two factors have also been reported in many papers. ${ }^{34-39}$ (3) The final factor is the onedimensional (1D) nanowire shape, which gives the small constituent nanocrystals higher grain interconnectivity compared to loosely packed nanoparticles with tiny interparticle contact areas. The $\tau_{\text {res }}$ values of the $\mathrm{In}_{2} \mathrm{O}_{3}$ flexible films are significantly shorter (3-6 s) compared to what has been reported in the literature, ${ }^{40}$ which reveals the fast gas diffusion in the sensor. Such fast gas diffusion is the result of the highly porous nature of the $\mathrm{In}_{2} \mathrm{O}_{3}$ nanowire film with its ultra-high surface-tovolume ratio, which allows faster gas diffusion into and out of the sensing layers. Moreover, due to the high working temperature $\left(260{ }^{\circ} \mathrm{C}\right)$, the oxygen diffusion at the surface of the porous $\mathrm{In}_{2} \mathrm{O}_{3}$ nanowire films will be much faster than at room temperature. The recovery reaction includes the following serial reactions: the diffusion of oxygen onto the sensing surface, the adsorption of oxygen, and the dissociation and ionization of oxygen. ${ }^{40}$ With both much smaller crystal sizes and ultra-high surface-to-volume ratios, the $\mathrm{In}_{2} \mathrm{O}_{3}$ flexible films exhibit high chemical reactivities and can more easily adsorb and ionize oxygen at a high working temperature $\left(260{ }^{\circ} \mathrm{C}\right)$. The superior 
recovery time is attributable to this promotion of surface reactions involving adsorption, dissociation, and ionization of oxygen.

\section{Conclusion}

In conclusion, we have reported for the first time a novel porous metal oxide film consisting of polycrystalline nanowires with ultra-small nanocrystals and a high density of ultra-fine nanopores, which was synthesized by a chemical conversion technique followed by filtration. The two-step method provides a feasible way to separately control the thickness of the porous film and the crystal size. Compared to previous reports, the as-synthesized metal oxide nanowires feature ultra-fine nanopores. Taking $\mathrm{In}_{2} \mathrm{O}_{3}$ as an example, porous and flexible $\mathrm{In}_{2} \mathrm{O}_{3}$ films, made of $\mathrm{In}_{2} \mathrm{O}_{3}$ polycrystalline nanowires with ultra-small nanocrystals (less than $10 \mathrm{~nm}$ ) and a high density of ultra-fine nanopores (1.6$3.1 \mathrm{~nm}$ ), have been successfully synthesized and show significantly higher sensitivities, as well as good reproducibility and faster response/recovery speeds towards ethanol gas compared to both commercial $\mathrm{SnO}_{2}$ thick films and $\mathrm{SnO}_{2}$ nanobelts because of their much smaller crystal sizes, ultra-high surface-to-volume ratios, nanoporous structure, and 1D nanowire structure, which induces unique charge transport paths. We believe that such functionally designed metal oxide flexible films will replace their traditional thick film counterparts, not only in gas sensors but also possibly in other functional devices.

\section{Acknowledgements}

This work is partly supported by the Australian Research Council through a Discovery Project (DP1094261), the National Basic Research Program of China (973 Program) grant No. 2007CB936300, the National High Technology Research and Development Program of China (863 Program) grant No. 2006AA03A107, and the National Natural Science Foundation of China (grant No. 50702073). We thank Dr Tania Silver for the English editing of this paper.

\section{Notes and references}

1 T. Seiyama, A. Kato, K. Fujiishi and M. Nagatani, Anal. Chem., 1962, 34, 1502-1503.

2 J. Du, D. Liang, H. Tang and X. Gao, Nano Lett., 2009, 9, 4348-4351.

3 N. Du, H. Zhang, B. D. Chen, X. Y. Ma, Z. H. Liu, J. B. Wu and D. R. Yang, Adv. Mater., 2007, 19, 1641-1645.

4 X. G. Han, M. S. Jin, S. F. Xie, Q. Kuang, Z. Y. Jiang, Y. Q. Jiang, Z. X. Xie and L. S. Zhang, Angew. Chem., Int. Ed., 2009, 48, 9180 9183.

5 A. Rosental, A. Tarre, A. Gerst, T. Uustare and V. Sammelselg, Sens. Actuators, B, 2001, 77, 297.

6 A. Rosental, A. Tarre, A. Gerst, J. Sundqvist, A. Hrsta, A. Aidla, J. Aarik, V. Sammelselg and T. Uustare, Sens. Actuators, B, 2003, 93, 552 .
7 M. Kroneld, S. Novikov, S. Saukko, P. Kuivalainen, P. Kostamo and V. Lantto, Sens. Actuators, B, 2006, 118, 110.

8 H. Ogawa, M. Nishikawa and A. Abe, J. Appl. Phys., 1982, 53, 4448.

9 N. Yamazoe, New approaches for improving semiconductor gas sensors, Sens. Actuators, B, 1991, 5, 7-19.

10 A. Rothschild and Y. Komem, J. Appl. Phys., 2004, 95, 6374.

11 E. R. Leite, I. T. Weber, E. Longo and J. A. Varela, Adv. Mater., 2000, 12, 956-968.

12 N. Pinna, G. Neri, M. Antonietti and M. Niederberger, Angew. Chem., Int. Ed., 2004, 116, 4445-4449.

13 Y. Liu, E. Koep and M. L. Liu, Chem. Mater., 2005, 17, 3997.

14 S. Peulon and D. Lincot, Adv. Mater., 1996, 8, 166.

15 A. Tricoli, M. Graf and S. E. Pratsinis, Adv. Funct. Mater., 2008, 18, 1969.

16 R. Khandelwal, A. P. Singh, A. Kapoor, S. Grigorescu, P. Miglietta, N. E. Stankova and A. Perrone, Opt. Laser Technol., 2009, 41, 89.

17 Y. H. Choi and S. H. Hong, Sens. Actuators, B, 2007, 125, 504.

18 R. H. A. Ras, M. Kemell, J. D. Wit, M. Ritala, G. T. Brinke, M. Leskelä and O. Ikkala, Adv. Mater., 2007, 19, 102.

19 M. G. Han and S. H. Foulger, Chem. Commun., 2004, 2154-2155.

20 H. D. Yu, D. S. Wang and M. Y. Han, J. Am. Chem. Soc., 2007, 129, 2333-2337.

21 J. Liu and D. F. Xue, Adv. Mater., 2008, 20, 1-6.

22 (a) L. Tian, H. L. Zou, J. X. Fu, X. F. Yang, Y. Wang, H. L. Guo, X. H. Fu, C. L. Liang, M. M. Wu, P. K. Shen and Q. M. Gao, Adv. Funct. Mater., 2010, 20, 617-623; (b) P. C. Xu, Z. X. Cheng, Q. Y. Pan, J. Q. Xu, Q. Xiang, W. J. Yu and Y. L. Chu, Sens. Actuators, B, 2008, 130, 802-808; (c) J. Y. Lao, J. Y. Huang, D. Z. Wang and Z. F. Ren, Adv. Mater., 2004, 16, 65-69; (d) Lin Xu, B. Dong, Y. Wang, X. Bai, Q. Liu and H. W. Song, Sens. Actuators, B, 2010, 147, 531-538.

23 L. Gao, Q. H. Zhang and J. G. Li, J. Mater. Chem., 2003, 13, 154-158.

24 L. W. Yin, Y. Bando, D. Golberg and M. S. Li, Adv. Mater., 2004, 16, 1833-1838.

25 S. D. Luo, W. Y. Zhou, Z. X. Zhang, X. Y. Dou, L. F. Liu, X. W. Zhao, D. F. Liu, L. Song, Y. J. Xiang, J. J. Zhou and S. S. Xie, Chem. Phys. Lett., 2005, 411, 361-365.

26 R. C. Weast, CRC Handbook of Chemistry and Physics, Academic, Florida, 1983-1984.

27 Y. D. Yin, R. M. Rioux, C. K. Erdonmez, S. Hughes, G. A. Somorjai and A. P. Alivisatos, Science, 2004, 304, 711-714.

28 J. Liu, W. J. Wang, Z. P. Guo, R. Zeng, S. X. Dou and X. L. Chen, Chem. Commun., 2010, 46, 3887-3889.

29 H. J. Fan, M. Knez, R. Scholz, K. Nielsch, E. Pippel, D. Hesse, M. Zacharias and U. Gösele, Nat. Mater., 2006, 5, 627.

30 H. J. Fan, M. Knez, R. Scholz, D. Hesse, K. Nielsch, M. Zacharias and U. Gösele, Nano Lett., 2007, 7, 993-997.

31 E. S. Toberer, T. D. Schladt and R. Seshadri, J. Am. Chem. Soc., 2006, 128, 1462-1463.

32 C. X. Wang, L. W. Yin, L. Y. Zhang, Y. X. Qi, N. Lun and N. N. Liu, Langmuir, 2010, 26, 12841-12848.

33 K. B. Zhang, L. L. Gu, D. L. Sun, X. L. Mo and G. R. Chen, Mater. Sci. Eng., B, 2010, 166, 104-107.

34 (a) B. R. Mehta and V. N. Singh, Pramana-J. Phys., 2005, 65, 949 958; (b) A. Gurlo, Nanoscale, 2011, 3, 154-165.

35 C. Xu, J. Tamaki, N. Miura and N. Yamazoe, Sens. Actuators, B, 1991, 3, 147-155.

36 A. Rothschild and Y. Komem, J. Appl. Phys., 2004, 95, 6374-6380.

37 L. Madler, T. Sahm, A. Gurlo, J. D. Grunwaldt, N. Barsan, U. Weimar and S. E. Pratsinis, J. Nanopart. Res., 2006, 8, 783-796.

38 A. Gurlo, N. Barsan, M. Ivanovskaya, U. Weimar and W. Gopel, Sens. Actuators, B, 1998, 47, 92-99.

39 M. E. Franke, T. J. Koplin and U. Simon, Small, 2006, 2, 36-50.

40 H. R. Kim, K. I. Choi, K. M. Kim, I. D. Kim, G. Z. Cao and J. H. Lee, Chem. Commun., 2010, 46, 5061-5063. 